Article

\title{
Development of Chitosan/Peptide Films: Physical, Antibacterial and Antioxidant Properties
}

\author{
Chen $\mathrm{Li}^{1,+}$, Jiliu Pei ${ }^{1}$, Shengyu Zhu ${ }^{1}$, Yukang Song ${ }^{1}$, Xiaohui Xiong ${ }^{1, *}$ and Feng Xue ${ }^{2}$ \\ 1 College of Food Science and Light Industry, Nanjing Tech University, Nanjing 211816, China; \\ lichenfs@njtech.edu.cn (C.L.); jiliupei@njtech.edu.cn (J.P.); 3802160215@njtech.edu.cn (S.Z.); \\ songyukang@njtech.edu.cn (Y.S.) \\ 2 School of Pharmacy, Nanjing University of Chinese Medicine, Nanjing 210023, China; xuefeng@njucm.edu.cn \\ * Correspondence: xxh@njtech.edu.cn; Tel.: +86-138-13362715 \\ † Current address: 30 Puzhu South Road, Pukou District, Nanjing 211816, China.
}

Received: 22 October 2020; Accepted: 4 December 2020; Published: 6 December 2020

check for updates

\begin{abstract}
Chitosan/peptide films were prepared by incorporating peptides $(0.4 \%, w / v)$ from soy, corn and caseins into chitosan films. The presence of peptides significantly affected the physical, antibacterial and antioxidative properties of chitosan films. Among these films, those containing corn peptide showed the best water vapor barrier properties, and the tensile strength and elongation at break increased to $24.80 \mathrm{Mpa}$ and $23.94 \%$, respectively. Characterization of surface hydrophobicity and thermal stability suggested the strongest intermolecular interactions between corn peptides and chitosan. Moreover, films containing casein peptides showed the highest antibacterial activity and radical scavenging activity. The DPPH scavenging rate of films containing casein peptides reached $46.11 \%$, and ABTS scavenging rate reached $66.79 \%$. These results indicate the chitosan/peptide films may be promising food packaging materials.
\end{abstract}

Keywords: chitosan-peptide films; physical property; antibacterial activity; antioxidant activity

\section{Introduction}

The plastic packaging materials, as a result of their persistent residues in the environment and unexpected interaction with food (heavy metals residues from packaging, e.g., cadmium or mercury), have become a threat to both environment and human health [1]. In recent years, the food packaging industry has been more inclined to develop biodegradable or edible films for food safety and environmental protection. Polysaccharides, such as cellulose, starch, chitosan, pullulan and alginate, are a class of suitable biopolymers in edible coatings and films formulation. Despite the hydrophilic nature of polysaccharides coatings and films, they are nontoxic, colorless, and have selective permeability for oxygen, and thus could be used in fruits, vegetables, seafood, and meat products $[2,3]$.

Chitosan-based films, among other polysaccharides films, have been widely explored due to their natural antimicrobial characteristics, great mechanical and gas barrier properties [4-6]. Through chemical modification and/or loaded with nanoparticles, chitosan-based films were able to act as excellent wound dressings, multifunctional textiles, as well as antibacterial fabrics. Hence, there has been increasingly research interest in applying them in food, biomedical and chemical industry [7-11]. However, its extensive application in food industry is still limited due to the poor water barrier property and lack of antioxidant ability [12]. Many studies have prepared chitosan films by blending into active ingredients, such as polyphenols, cinnamaldehyde, essential oils, and natural extracts from plants [13-18] to promote its free radical scavenging activity. These natural substances have been 
proved effective and can act as alternative antioxidants in the films; however, it is still necessary to discover highly active compounds to prevent oxidation damage and improve food quality.

Bioactive peptides, due to its ability to reduce the formation of oxidative products, can be explored as natural new antioxidant food ingredients [19]. Some peptides have also been incorporated into edible films to improve its physiochemical properties. Giménez et al. incorporated gelation hydrolysates into squid skin gelation films, which gave rise to the antioxidant properties of films, but led to detriment of mechanical properties and water vapor barrier properties [20]. Zhang et al. discovered that by mixing rapeseed protein hydrolysate into chitosan films, the mechanical and water vapor barrier properties were enhanced, along with the antimicrobial properties improvement when the added hydrolysate possessed the highest degree of hydrolysis (12\%) [21]. Furthermore, some studies grafted peptide onto chitosan, and the resulting films showed strong antioxidant activity, making them excellent for use in wound healing materials [22,23]. However, the number of studies about applying peptide to edible films or coatings is still limited, and comparisons of the effects of different peptides on film properties are also deficient.

Soy and corn are the leading corps cultivated in China; therefore, peptides from soy and corn are both abundant and cost-effective [24]. As major protein fractions in milk protein, caseins are also excellent precursors of antioxidant peptides. In this study, peptides from soy, corn and caseins were individually incorporated into chitosan films. The aim was to evaluate the effects of different peptides on physical, antioxidant and antimicrobial properties of the films, as well as to explore their potentiality to be used as active ingredient in food packaging.

\section{Materials and Methods}

\subsection{Materials and Chemicals}

Chitosan (90\% deacetylation, molecular weight $=200-300 \mathrm{KDa})$, casein peptides, strains of Escherichia coli (CMCC 44102) and Bacillus subtilis (CMCC 63501) were purchased from Shanghai Yuanye biotechnology Co., Ltd. (Shanghai, China). The molecular weights of peptides were measured according to our previous study [25], and the molecular mass distributions of peptides are provided in Figure S1. The molecular mass of main fractions for three peptides was in the range of 5.0-0.6 KDa. Glycerol was purchased from Macklin Biochemical Co., Ltd. (Shanghai, China). Soy and corn peptides were purchased from Shandong Tianmei biotechnology Co., Ltd. (Shandong, China).

\subsection{Preparation of Film-Forming Solution}

The film-forming solution was prepared following the procedure described by Zhang et al. with slight modifications [21]. Chitosan $(1.6 \mathrm{~g})$ and glycerol $(0.4 \mathrm{~g})$ was dispersed in $80 \mathrm{~mL}$ acetic acid $(1 \%, w / v)$ by stirring for at least $12 \mathrm{~h}\left(4{ }^{\circ} \mathrm{C}\right)$. The soy/corn/casein peptides $(0.4 \mathrm{~g})$ were dissolved in $20 \mathrm{~mL}$ distilled water by stirring for at least $2 \mathrm{~h}\left(4^{\circ} \mathrm{C}\right)$. Then the peptide solution was added into the chitosan solution and stirred for an additional $1 \mathrm{~h}$. The film-forming solution ( $2 \%$ chitosan, $w / v)$ that did not contain peptides was used as the control.

\subsection{Preparation of Films}

The films were prepared according to our previously published method [26]. An amount of $60 \mathrm{~g}$ of each solution described in Section 2.2 was casted on leveled polytetrafluoroethylene plates $\left(42 \times 42 \mathrm{~cm}^{2}\right)$ and then dried at $30^{\circ} \mathrm{C}$ and $43 \%$ relative humidity using a ventilated chamber (KBF720, Binder, Germany) for $18 \mathrm{~h}$. 


\subsection{Characterization of Films}

2.4.1. Measurement of Color, Thickness, Light Transmission, Swelling Ability, Water Vapor Permeability and Mechanical Properties

The color parameters, i.e., $L$ (lightness), $a^{*}$ (redness and greenness) and $b^{*}$ (yellowness and blueness) of films were measured using a Hunter-Lab colorimeter (Reston, VA, USA). The whiteness index and $\Delta E$ were calculated according to a previous study [27]. The thickness of the films was measured with a micrometer with the accuracy of $1 \mu \mathrm{m}$. The light transmission of films was measured according to Rubilar's method using a microplate spectrophotometer (Spark 10M, Tecan, Switzerland) [27]. The water vapor permeability (WVP) of films was measured by using a ASTM E96/E96M gravimetric method [28]. Films were placed in well-sealed permeation cells containing silica gel and kept in ventilated chamber at $25{ }^{\circ} \mathrm{C}$ and $75 \%$. Tensile strength (TS) and elongation at break (EB) of the films were measured using a TA-XT2i texture analyzer (Stable Microsystems, London, UK). The initial distance of separation and cross-head speed were fixed at $50 \mathrm{~mm}$ and $1 \mathrm{~mm} / \mathrm{s}$, respectively [29].

\subsubsection{Contact Angle}

Contact angle of film was measured using a goniometer (OCA15EC, DataPhysics Instruments, Stuttgart, Germany). Deionized water $(10 \mu \mathrm{L})$ was placed on the films and the image was recorded after $5 \mathrm{~s}$. The contact angle was defined as the angle between baseline and the tangent to the drop boundary. Five measurements were performed on each film.

2.4.3. Acquiring Fourier Transform Infrared Spectroscopy (FTIR), X-ray Diffractometry (XRD), Differential Scanning Calorimetry (DSC) and Thermogravimetric (TG) Curves of Films

Films were dried in a desiccator with silica gel for 7 days before FTIR analysis. The dried films were then cut into $1.5 \mathrm{~cm} \times 1.5 \mathrm{~cm}$ and scanned using FTIR-7600 spectroscope (Lambda, Miami, FL, USA) with a horizontal ATR. The spectra were recorded in the wavenumber range of $4000-400 \mathrm{~cm}^{-1}$ at $4 \mathrm{~cm}^{-1}$ resolution. X-ray diffraction patterns were performed by Smartlab-3 $\mathrm{kw}$ X-ray diffractometer (Rigaku, Tokyo, Japan) with $\mathrm{Cu} K \alpha$ radiation at $40 \mathrm{kV}$ and $30 \mathrm{~mA}$ at a scan rate $10^{\circ} \mathrm{min}^{-1}$ and the patterns were recorded in the range of $2 \theta$ from $5^{\circ}$ to $55^{\circ}$. The DSC tests were performed using a thermal analyzer (TA Instruments, New Castle, DE, USA). Film (3-6 mg) was sealed in aluminum pan and heated at a rate $10{ }^{\circ} \mathrm{C} \cdot \mathrm{min}^{-1}$ from 25 to $250^{\circ} \mathrm{C}$ under $\mathrm{N}_{2}$ atmosphere. Thermal gravimetric analysis was performed by using Q500 thermal analyzer (TA Instruments, New Castle, DE, USA). Film samples $\left(5 \mathrm{mg}\right.$ ) were heated from 35 to $800^{\circ} \mathrm{C}$ at a heating rate of $10^{\circ} \mathrm{C} \cdot \mathrm{min}^{-1}$ under $\mathrm{N}_{2}$ atmosphere.

\subsubsection{Observation of Surface Morphology}

The surface morphology of the films was acquired using a scanning electron microscope (SEM) system (MERLIN SEM, ZEISS, Oberkochen, Germany). The film surfaces exposed to air during film forming process were sputter coated with gold-palladium before acquiring the SEM micrographs. To observe the microstructure of the cross-section, the films were fractured by immersing in liquid nitrogen and scanned using the same SEM. The voltage used was $5 \mathrm{kV}$, and the magnifications for surface and cross-section morphology were 1000× and 1200×, respectively.

\subsection{Antibacterial and Antioxidant Activities of Films}

Antibacterial activity tests of films were carried out according to our previous study [26]. Luria-Bertani medium $(25 \mathrm{~mL})$ was poured into petri dishes, which had been previously seeded with $0.1 \mathrm{~mL}$ of inoculum containing about $10^{6} \mathrm{CFU} / \mathrm{mL}$ cells of indicator bacterium (Escherichia coli or Bacillus subtilis). The films $\left(0.6 \mathrm{~cm}\right.$ diameter) were placed on the plates and then incubated at $37^{\circ} \mathrm{C}$ for $24 \mathrm{~h}$. The diameter of inhibitory zone surrounding film disc as well as the contact area of the film with agar surface were measured and recorded. 
The antioxidant capacity of film was evaluated by 1,1-diphenyl-2-picrylhydrazyl (DPPH) and diammonium 2,2'-azino-bis(3-ethylbenzothiazoline-6-sulfonate (ABTS) radical scavenging assay according to our previous study [26]. Briefly, film was mixed with DPPH $(0.10 \mathrm{mM})$ solution or ABTS $(7 \mathrm{mM})$ to obtain a final concentration of $0.1 \mathrm{mg} / \mathrm{mL}$. After incubation, the absorbance of $200 \mu \mathrm{L}$ sample was measured using spectrophotometer and scavenging rate was calculated.

\subsection{Statistical Analysis}

All the tests were performed in triplicate and the data obtained were analyzed by one-way analysis of variance using Statistical Product and Service Solutions (SPSS) for Windows version 17.0. Values are expressed as means \pm standard deviation. Duncan's multiple range test was used to identify significant differences $(p<0.05)$ between any two mean values.

\section{Results and Discussion}

\subsection{Physical Properties of Films}

\subsubsection{Color, Thickness, Water Vapor Permeability, Mechanical Properties and Light Transmission}

As shown in Figure 1, the addition of peptides significantly decreased the values of lightness $(L)$ and the white index (WI). This decrease can be attributed to the colored substances present in peptides. On the other hand, Maillard reaction between chitosan and peptides might occur during the film-forming process [30], which could also result in the brown color of films. The $\Delta E$ value indicates the total color difference of the standard color plate. The $\Delta E$ value of the peptides films was much higher than control, indicated that the color of peptides films was relatively deep and less opaque than control. Furthermore, the type of peptides significantly affected the color of films, the color of film incorporated with corn peptides was much deeper than others.

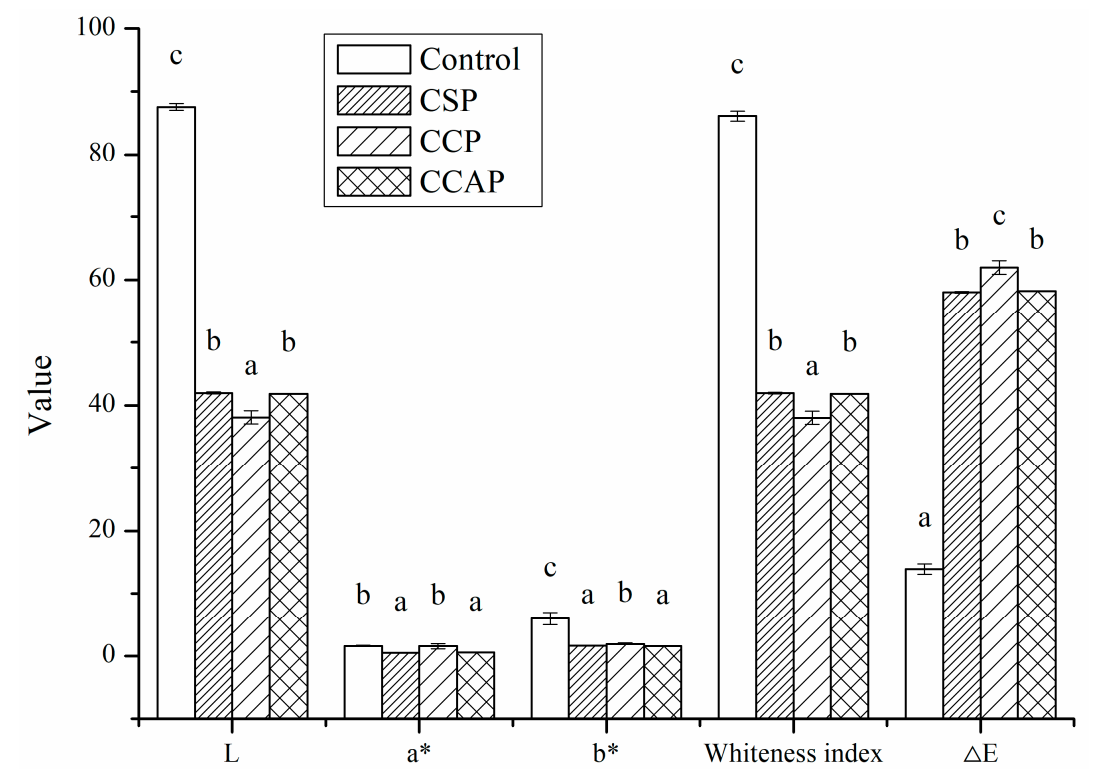

Figure 1. Color parameters $\left(L, a^{*}, b^{*}\right)$ of chitosan (control) and peptide-containing films. CSP: films from chitosan and soy protein peptides; CCP: films from chitosan and corn protein peptides; CCAP: films from chitosan and casein peptides. Results having different letters $(a-c)$ in same pattern are significantly different $(p<0.05)$.

It is well known that the thickness has an important influence on the physical properties of films, such as transparency, barrier properties and mechanical properties. As shown in Table 1, the thickness of films was neither affected by the addition of peptides nor type of peptides. In fact, the thickness 
of films is correlated with the non-solvent total mass in the film forming solution. Therefore, no significant $(p<0.05)$ difference in thickness observed could be attributed to the same solid content in the film-forming solution [31]. Previous research has also proved that the thickness of the film is related to the concentration of constituents in the film-forming solution [32].

Table 1. Thickness, water vapor permeability (WVP), tensile strength (TS) and elongation at break (EB) of chitosan films and films containing peptides.

\begin{tabular}{ccccc}
\hline Sample & Thickness $(\boldsymbol{\mu m})$ & WVP g/(m·s·Pa) $\times \mathbf{1 0}^{-\mathbf{8}}$ & TS (MPa) & EB (\%) \\
\hline Control & $19.8 \pm 5.8^{\mathrm{a}}$ & $1.85 \pm 0.08^{\mathrm{c}}$ & $9.81 \pm 0.17^{\mathrm{b}}$ & $16.02 \pm 1.31^{\mathrm{b}}$ \\
CSP & $26.7 \pm 4.7^{\mathrm{a}}$ & $2.96 \pm 0.14^{\mathrm{d}}$ & $6.13 \pm 0.51^{\mathrm{a}}$ & $14.54 \pm 0.97^{\mathrm{ab}}$ \\
CCP & $28.6 \pm 3.9^{\mathrm{a}}$ & $0.83 \pm 0.07^{\mathrm{a}}$ & $24.80 \pm 1.92^{\mathrm{d}}$ & $23.94 \pm 1.07^{\mathrm{c}}$ \\
CCAP & $24.4 \pm 3.4^{\mathrm{a}}$ & $1.08 \pm 0.16^{\mathrm{b}}$ & $20.32 \pm 0.64^{\mathrm{c}}$ & $13.40 \pm 1.48^{\mathrm{a}}$ \\
\hline
\end{tabular}

CSP: films from chitosan and soy protein peptides; CCP: films from chitosan and corn protein peptides; CCAP: films from chitosan and casein peptides. Results having different letters $(a-d)$ within a column are significantly different $(p<0.05)$.

As shown in Table 1, incorporation of peptides significantly $(p<0.05)$ affected the water vapor barrier ability of films. As compared with the control, the addition of corn and casein peptides was able to decrease the WVP values of films. The improvement of water vapor barrier ability can be attributed to the decrease in the concentration of chitosan. It is well known that chitosan is a hydrophilic polymer and has poor water resistance [33]. When the chitosan concentration was lower, the moisture permeability of the composite film was lower. Similar research results have been reported indicting that the water vapor transmission of the composite film increases with the increase of chitosan ratio [21]. On the other hand, with the addition of the corn or casein peptides, the peptides and chitosan might be fully integrated in the form of non-covalent or covalent bonds and filled in the respective network structure, making the composite film structure closer. Previous studies have proved that water vapor barrier ability of film could be improved by both enhancement of network [34] and reinforcement of structure [35]. Furthermore, the films with the addition of corn peptides exhibited the lowest value of WVP. This is probably due to the high level of non-polar amino acids in corn peptides, which led to the corn protein-based films having high water barrier performance [36,37]. However, the addition of soy peptides led to the increase in WVP. This result indicated that incorporation of soy peptides could disrupt the intermolecular interactions of film, which might result in the less compact structure. Previous study has also proved that weakened intermolecular interactions and loose structure in film lead to a decrease in vapor barrier ability [26].

As shown in Table 1 , the addition of peptides significantly $(p<0.05)$ affected the mechanical properties of films. As compared with control, the addition of corn or casein peptides significantly $(p<0.05)$ increased the tensile strength of films. This is probably due to the formation of chemical bonds between the hydroxyl group in chitosan and amino group or carboxyl group in peptides. Previous study has also shown that the chemical bonds formed between proteins and polysaccharides lead to an increase in the tensile strength of the composite films [38]. However, the addition of soy peptides decreases the tensile strength of films. One of the explanations is that the existence of soy peptides disrupted the intermolecular force in chitosan, resulting in the decrease in TS of the composite films. Previous study has also shown that the addition of protein hydrolysates can break down the covalent bond and hydrogen bond in chitosan films, thus decreasing the TS of the composite films [21]. Furthermore, the addition of corn peptides significantly $(p<0.05)$ increased the EB of films compared to control. This result is inconsistent with previous study suggesting that the increase in tensile strength usually leads to a decrease in flexibility of the films [26]. The increase in flexibility could be attributed to the high level of non-polar amino acids in corn peptides, which might lead to the increasing of distance between biopolymer chains [39]. The improvement of flexibility of chitosan films by the addition of protein hydrolysate has also been proved by previous study [21]. 
As shown in Figure 2, the addition of peptides decreased the light transmission of chitosan films in the range of 380-1000 $\mathrm{nm}$. This result indicated that peptides might affect the light scattering and transparency of films. However, the increase of light transmission in the 300-380 $\mathrm{nm}$ range of soy peptide films was observed. Usually, the addition of peptides could decrease the penetration of UV light due to the fact that aromatic amino acids (e.g., tryptophan, tyrosine) in peptides absorb UV light below $380 \mathrm{~nm}$ [40]. The opposite result for CSP indicated that absorption of aromatic amino acids might be disrupted due to the incompatibility between the chitosan and soy peptides. On the other hand, the opposite result could also be attributed to the fact that light transmission of chitosan-based films in the 300-380 nm range is irregular, which was also found by Liu et al. in their report [41]. Furthermore, the light transmission of the films was also affected by the type of peptides used and that the lowest light transmission was observed in film loaded with corn peptides. This is probably due to the fact that ability of corn peptides to scatter and absorb light might be better than others or films loaded with corn peptides might possessed more compact structure. Previous study has shown that the films that possess a more compact structure have less transparent ability [42,43].

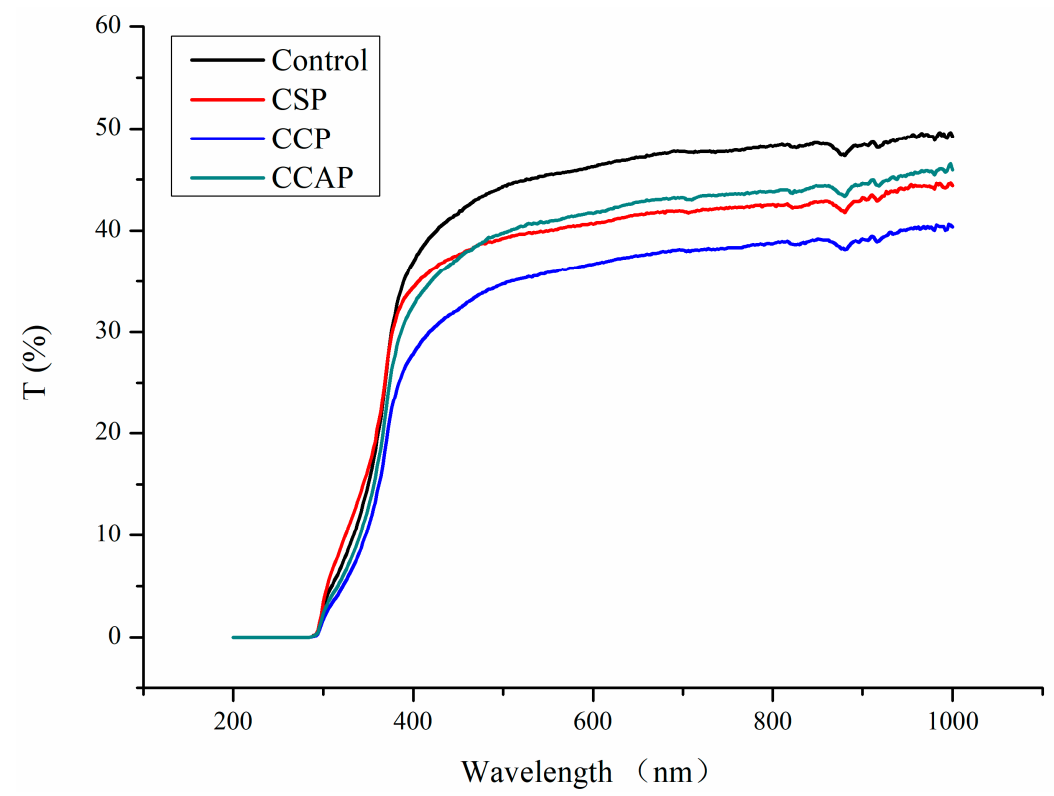

Figure 2. Light transmission of chitosan (control) and peptide-containing films. CSP: films from chitosan and soy protein peptides; CCP: films from chitosan and corn protein peptides; CCAP: films from chitosan and casein peptides.

\subsubsection{Surface Hydrophobicity}

Water contact angle is widely used as an indicator of the wettability of a film surface and moisture transport through it. As shown in Figure 3, the contact angle of the control films, CSP, CCP and CCAP were $92.7^{\circ} \pm 0.23^{\circ}, 86.8^{\circ} \pm 0.97^{\circ}, 95.0^{\circ} \pm 0.37^{\circ}$ and $94.2^{\circ} \pm 0.24^{\circ}$, respectively. The contact angle of were chitosan films was affected by the addition of peptides. The films containing corn peptides exhibited the highest contact angle among other films. This can be attributed to the higher hydrophobic nature, due to the high level of non-polar amino acids in corn peptides [30]. Furthermore, this highest contact angle also further explains why the films loaded with corn peptides showed the lowest water vapor permeability $[26,44]$. 


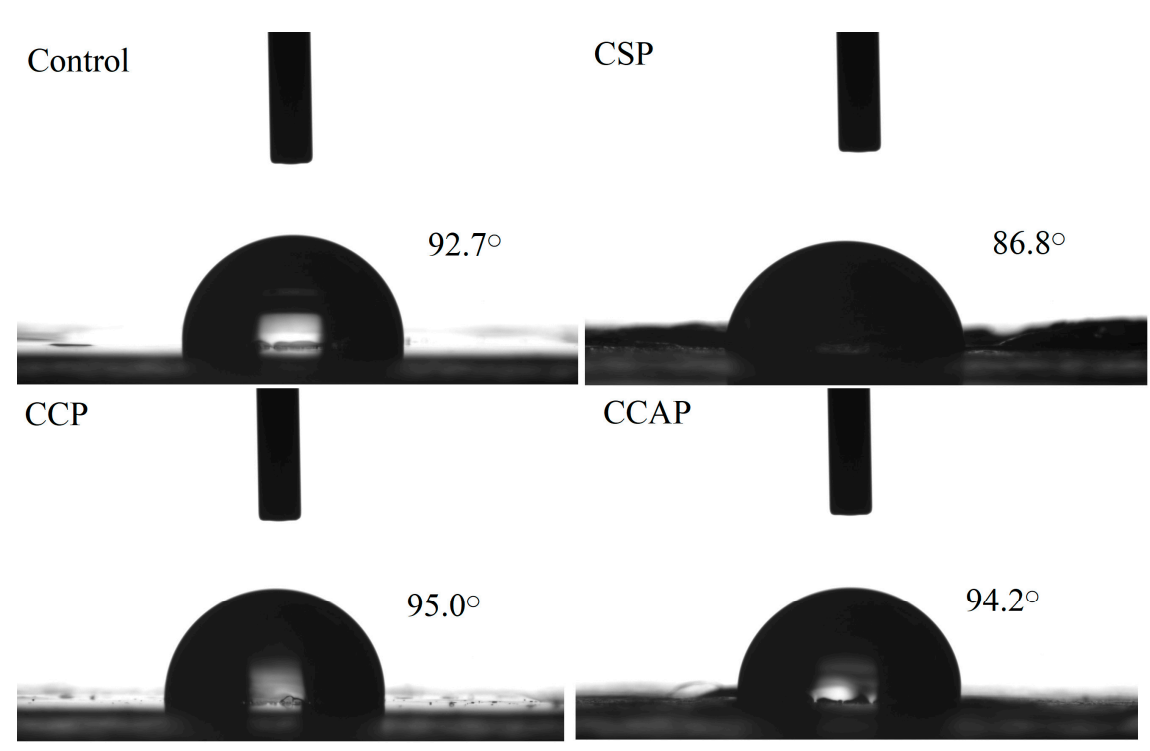

Figure 3. Surface hydrophobicity of chitosan (control) and peptide-containing films. CSP: films from chitosan and soy protein peptides; CCP: films from chitosan and corn protein peptides; CCAP: films from chitosan and casein peptides.

\subsubsection{Fourier Transform Infrared Spectroscopy (FTIR)}

Fourier transform infrared spectroscopy can be used to evaluate the interactions between chitosan and peptides molecules and changes in the functional groups. In chitosan films (as shown in Figure 4), the broad absorption bands at 3230, 2920 and $1027 \mathrm{~cm}^{-1}$ represented the stretching vibration of hydrogen bonding groups, $\mathrm{C}-\mathrm{H}$ of methyl and the $\mathrm{C}-\mathrm{O}-\mathrm{C}$ groups (glycosidic linkage) [21,30], respectively. For the films with the peptides, the broad bands of amide-A associated with $\mathrm{N}-\mathrm{H}$ and $\mathrm{O}-\mathrm{H}$ stretching vibrations shifted gradually to higher wavenumber, suggesting that the hydrogen bonds in chitosan films might be broken down by the addition of peptides. This is probably due to the formation of electrostatic interaction between the cationic groups of chitosan and the anionic groups of peptides [35]. Furthermore, the appearance of a new peak at $1250 \mathrm{~cm}^{-1}$ was observed in films with corn peptides, which could be attributed to the occurrence of Maillard reaction between $\mathrm{OH}$ group (chitosan) and amino groups (corn peptides) [45]. Therefore, electrostatic interaction and conjugation between chitosan and corn peptides might contribute to the strong interactions among components, which might lead to the formation of more compact structure. This result also helps to explain why films with corn peptides exhibited better vapor barrier ability, tensile strength and less transparent ability. 


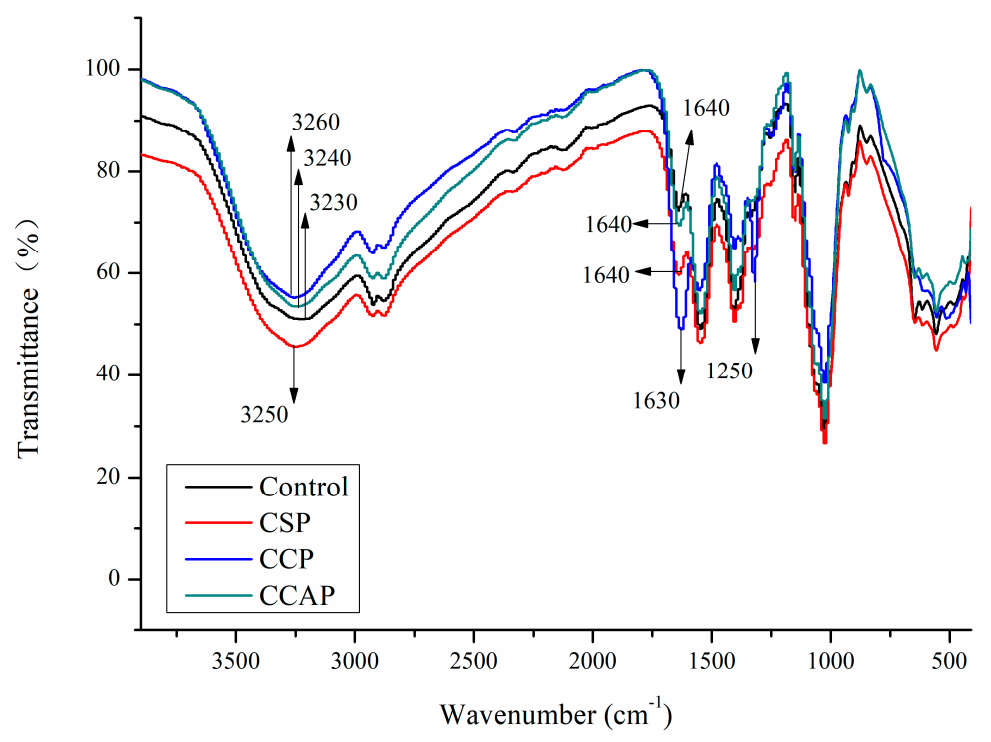

Figure 4. FTIR spectra of chitosan (control) and peptide-containing films. CSP: films from chitosan and soy protein peptides; CCP: films from chitosan and corn protein peptides; CCAP: films from chitosan and casein peptides.

\subsubsection{X-ray Diffraction (XRD) Patterns}

As shown in Figure 5, chitosan films exhibited two obvious diffraction peaks at $11^{\circ}$ and $22^{\circ}$. Obviously, the diffraction peak of film at $22^{\circ}$ corresponding to the regular crystal lattice of chitosan [30] became flatter after incorporation of peptides, indicating the better compatibility among components [46]. The peak at $11^{\circ}$ of $2 \theta$ was assigned to the hydrated crystals due to the integration of water molecules in the crystal lattice. Furthermore, the type of peptides also affected the diffraction peak of film and the lowest intensity of peak was observed in film containing corn peptides. This is probably due to the formation of new intermolecular interactions between chitosan and corn peptides, which destroyed the original crystalline domains of chitosan [30]. This result was consistent with the conclusion from FTIR analysis and in agreement with the improvement in physical properties of film containing corn peptides.

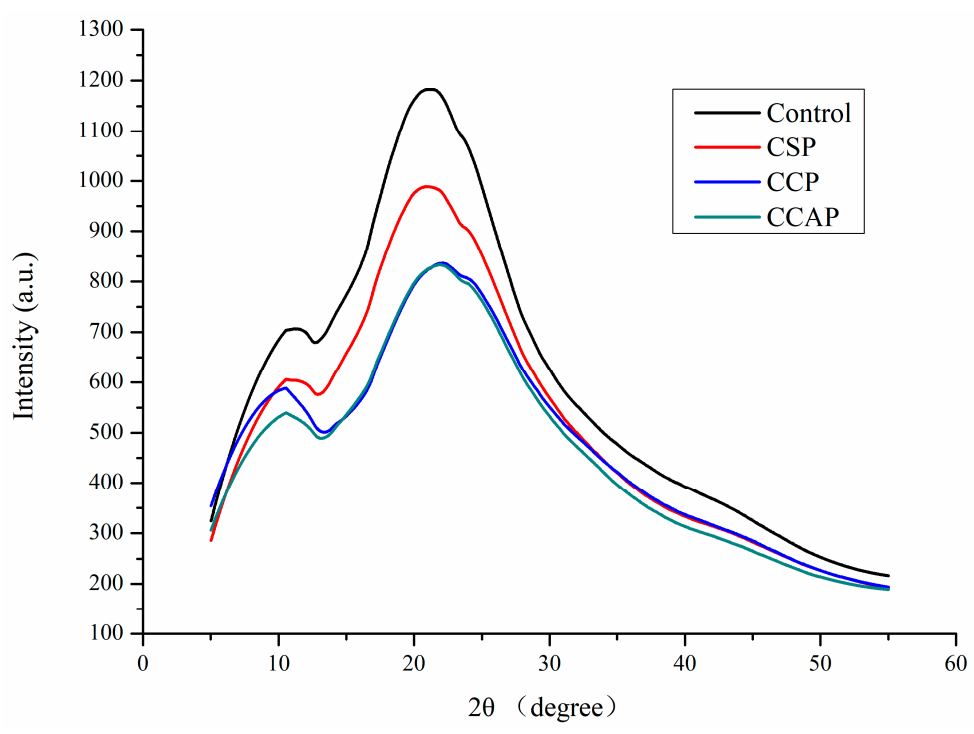

Figure 5. XRD patterns of chitosan (control) and peptide-containing films. CSP: films from chitosan and soy protein peptides; CCP: films from chitosan and corn protein peptides; CCAP: films from chitosan and casein peptides. 


\subsubsection{Thermal Properties}

As shown in Figure 6, three steps of transformations corresponding to the main stages of mass loss were observed from DTG curves, which is similar to the reported chitosan-based edible films [47]. The first step observed from 30 to $130{ }^{\circ} \mathrm{C}$ was attributed to the loss of small molecular substances including water and acetic acid, which is similar with previous study [13]. In this stage, the mass loss is lower in the films containing corn or casein peptides as compared to the control films. However, for the soy peptides films, the weight loss is higher than control. This result indicated that corn or casein peptide-containing films possess higher water or acetic acid and the soy peptide-containing films present lower water or acetic acid content. Combined with DSC (as shown in Figure 7), the peak of the endothermic value of films containing corn or casein peptides shifted to the direction of high temperature, while films containing soy peptides shifted in the direction of low temperature as compared to the control films. A second mass loss was observed from 130 to $220^{\circ} \mathrm{C}$, which is related to the evaporation of entrapped water through hydrogen bonds or glycerol $[48,49]$. In this stage, the mass loss of corn peptide-containing films is not as obvious as others, which indicated a change in the structure of films [47]. The third step was observed from 220 to $400{ }^{\circ} \mathrm{C}$, which corresponds to the degradation or the decomposition of chitosan chains [50]. In this stage, temperature of maximum degradation $\left(T_{\max }\right)$ could be obtained from curve. The $T_{\max }$ of $\mathrm{CCP}\left(307^{\circ} \mathrm{C}\right)$ were higher than others, which indicated better thermal resistance in corn peptide-containing films due to the generation of new interactions between chitosan and peptides. Combined with DSC (as shown in Figure 7), exothermic peaks at 250 to $300^{\circ} \mathrm{C}$ were observed in CSP, CCAP and control films, which can be attributed to the decomposition of chitosan chains [41]. However, no exothermic peak was observed in CCP. This result further confirmed the CCP possessed better thermal stability. Moreover, the residual mass for CCP and $\mathrm{CCAP}$ at $800{ }^{\circ} \mathrm{C}$ was higher than others, indicating a more thermally stable matrix in CCP and CCAP. Previous study also attributed the higher residual mass of chitosan-based films into more thermally stable matrix [47].

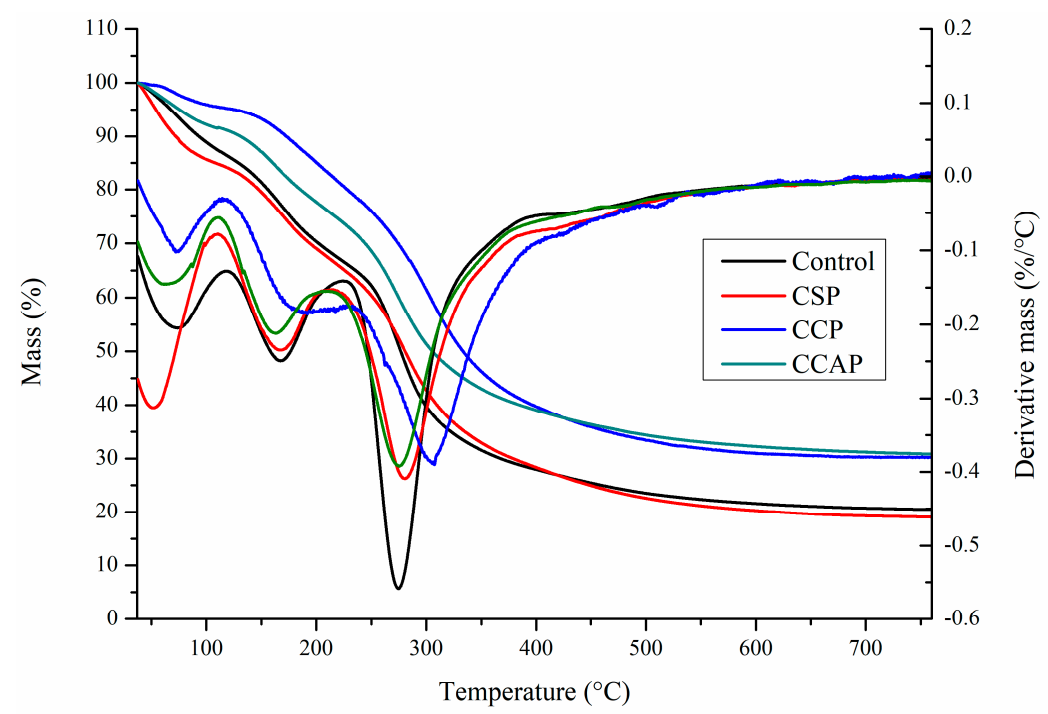

Figure 6. TG thermograms of chitosan (control) and peptide-containing films. CSP: films from chitosan and soy protein peptides; CCP: films from chitosan and corn protein peptides; CCAP: films from chitosan and casein peptides. 


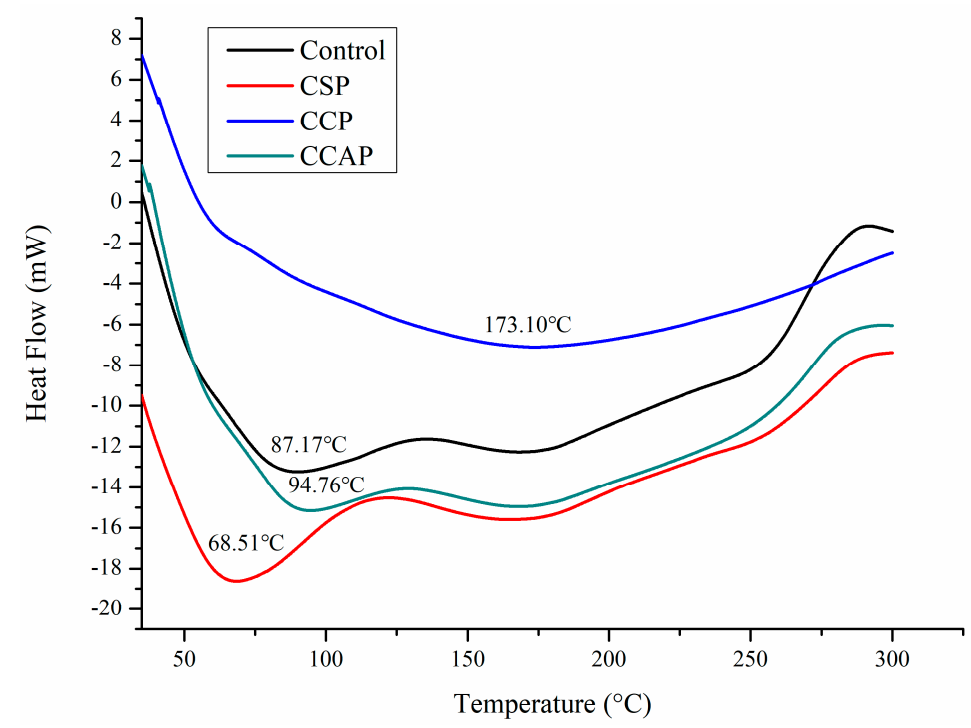

Figure 7. DSC curves of chitosan (control) and peptide-containing films. CSP: films from chitosan and soy protein peptides; CCP: films from chitosan and corn protein peptides; CCAP: films from chitosan and casein peptides.

\subsubsection{Microstructure of Films}

As shown in Figure 8, the surface of chitosan films appeared to be smoother and more uniform than the films containing peptides. The films seemed to be more fragmented with the addition of soy peptides, which suggested that the structural rearrangement of molecules occurred in the film matrix in the presence of soy peptides. This result further explains why the film containing soy peptides showed the lowest water barrier properties, tensile strength and thermal stability. The surface of films with the addition of corn and casein peptides appeared to be rougher than that of the control, which further explains why the film containing corn and casein peptides possessed the higher surface hydrophobicity. Furthermore, the films with the addition of corn and casein peptides exhibited a more compact cross-section than the control. This is probably due to the strong interaction and better compatibility between chitosan and peptides. The more compacted structure also helps to understand why films with the addition of corn and casein peptides showed an improvement in the water barrier properties, tensile strength and thermal stability.
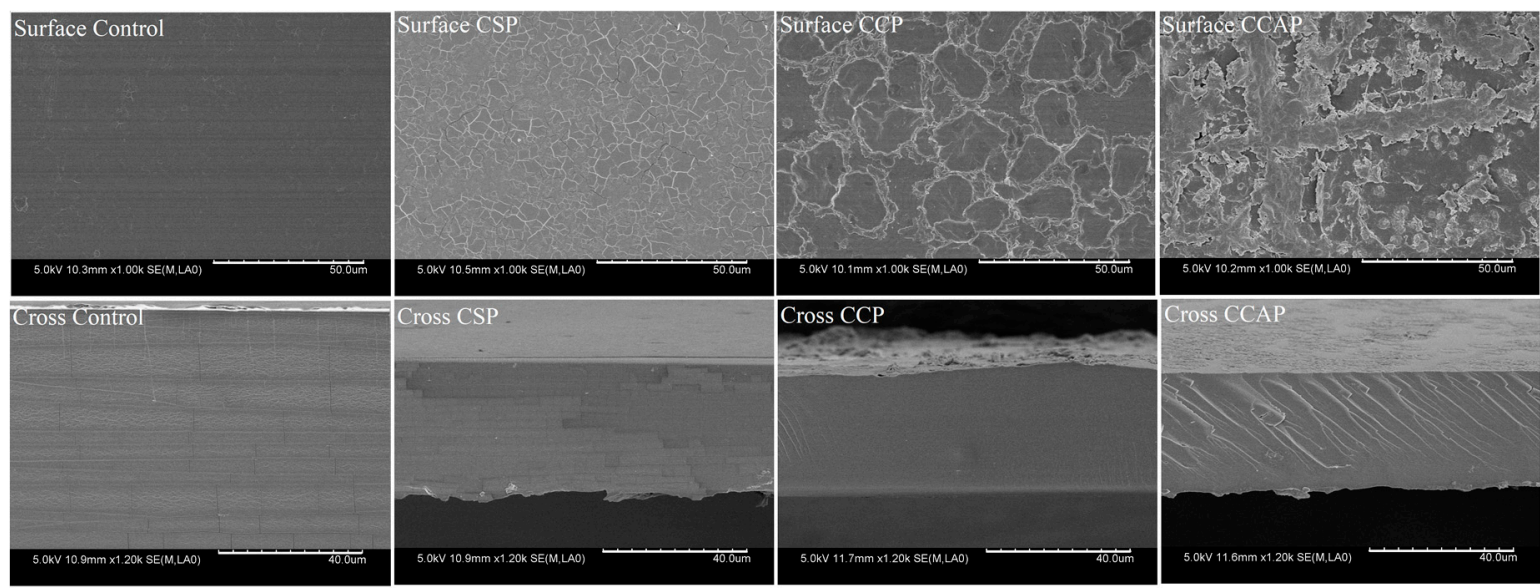

Figure 8. SEM images of the surface and cross-section of chitosan (control) and peptide-containing films. CSP: films from chitosan and soy protein peptides; CCP: films from chitosan and corn protein peptides; CCAP: films from chitosan and casein peptides. 


\subsection{Antibacterial and Antioxidant Activity}

As shown in Figure 9, all films exhibited antibacterial activity, due to the presence of chitosan. It is well known that chitosan is a kind of natural polymer that is abundant in the shell of shrimp and crab [51]. Chitosan not only has good film-forming properties [52], but also exhibits excellent antibacterial properties due to the many reactive amino side groups in chitosan structure, which could lead to the leakage of the intracellular constituents of the microorganisms [53]. Furthermore, the antibacterial activity of films was not significantly improved with the addition of soy or corn peptides. However, the addition of casein peptides enhanced the antibacterial activity of films. The diameter of inhabitation zone of CCAP for Escherichia coli and Bacillus subtilis increased by $28.9 \%$ and $21.6 \%$, respectively. This is probably due to the fact that caseins are known to be an important source of antimicrobial peptides [54]. The casecidins identified from hydrolysates of caseins exhibited activity against bacteria [55]. Hayes et al. identified three peptides from bovine casein exerting antibacterial activity against pathogenic strains of Cronobacter sakazakii [56]. Two peptides, corresponding to $f$ (21-29) and $\mathrm{f}(30-37)$, were also obtained from bovine caseins and exhibited strong activity against Enterobacter sakazakii [57]. Another cationic peptide derived from the casein has shown a broad spectrum of activity against Gram-positive and -negative bacteria [58]. Therefore, the addition of casein peptides makes chitosan-based films as a potential active packaging film to inhibit the growth of microorganism in food.

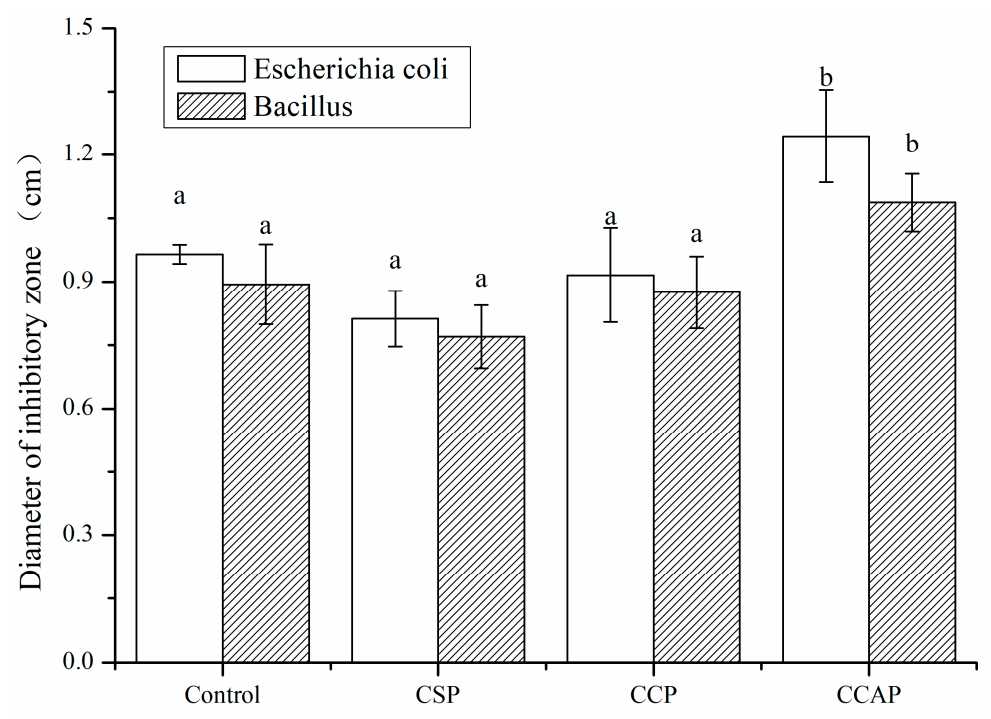

Figure 9. Antibacterial activity of chitosan (control) and peptide-containing films. CSP: films from chitosan and soy protein peptides; CCP: films from chitosan and corn protein peptides; CCAP: films from chitosan and casein peptides. Results having different letters $(a, b)$ in same pattern are significantly different $(p<0.05)$.

The antioxidant capacity of protein-derived peptides has been reported in a growing number of studies [19]. Proteins from animals, plants and microorganisms have been considered as the source of antioxidant peptides, which not only strengthen treatment of oxidation-related diseases but also delay the oxidation of food [59]. Although some antioxidant peptides, such as soy peptides, corn peptides and casein peptides have been commercialized. However, comparative studies concerning the antioxidant activity of active packaging films based on those peptides have been rarely conducted. As shown in Figure 10, the incorporation of soy, corn and casein peptides could significantly improve the scavenging capacity of chitosan films due to the antioxidant activity of peptides. The DPPH scavenging rates of CSP, CCP and CCAP were 3.7, 3.3 and 8.9 times higher than that of chitosan films. The ABTS scavenging rates of CSP, CCP and CCAP were 3.4, 3.3 and 3.6 times higher than that of chitosan films. Previous studies have proved that soy, corn and caseins are good sources of antioxidant 
peptides [60-62]. Furthermore, the antioxidant activity of films was different depending on the type of peptides used. CCAP exhibited the highest radical scavenging capacity, with DPPH scavenging rate reaching $46.11 \%$ and ABTS scavenging rate reaching $66.79 \%$, which might make it a potential active packaging film for preventing oxidation of food.

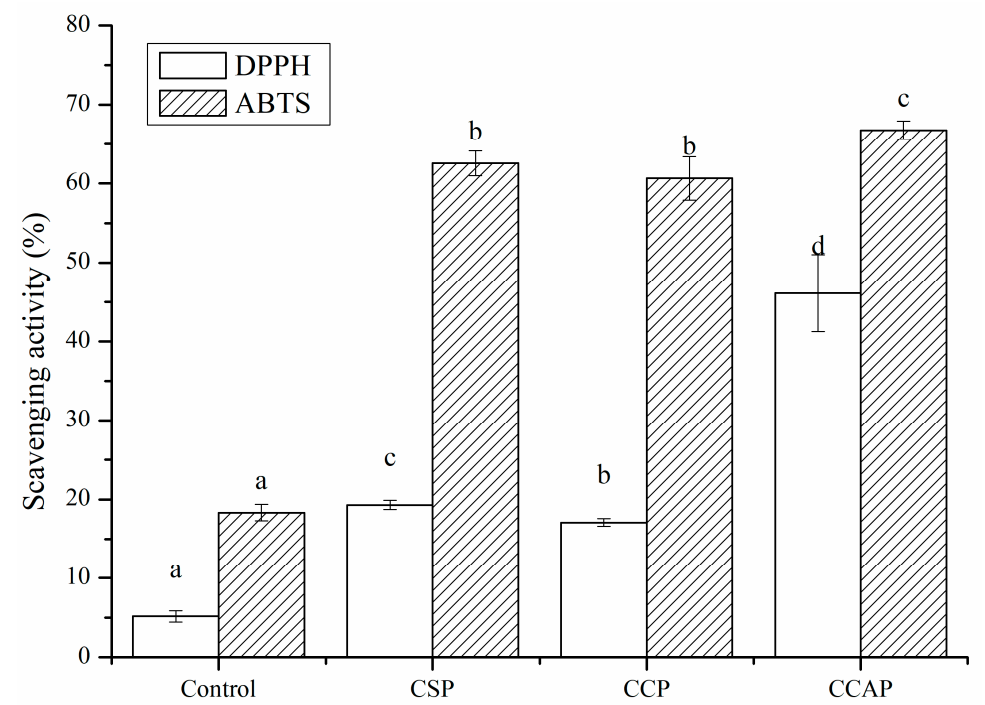

Figure 10. Antioxidant activity of chitosan (control) and peptide-containing films. CSP: films from chitosan and soy protein peptides; CCP: films from chitosan and corn protein peptides; CCAP: films from chitosan and casein peptides. Results having different letters $(a-d)$ in same pattern are significantly different $(p<0.05)$.

\section{Conclusions}

Peptides $(0.4 \%, w / v)$ from soy, corn and caseins were incorporated into chitosan films to form chitosan/peptide films. It was found that the type of peptides affected the physical, structural, antibacterial and antioxidant properties of peptide-containing films. The formation of chemical bonds between corn peptides and chitosan enhanced the inter-molecular interaction among the components, leading to the improvement of water barrier properties, mechanical properties and thermal stability. The addition of casein peptides exhibited the highest radical scavenging activity among all films, with DPPH scavenging rate reaching $46.11 \%$ and ABTS scavenging rate reaching $66.79 \%$. The film containing casein peptides also exhibited inhibitory effect against Escherichia coli and Bacillussubtilis. Therefore, the chitosan-based films containing corn or casein peptides could be applied as promising materials for food packaging.

Supplementary Materials: The following are available online at http://www.mdpi.com/2079-6412/10/12/1193/s1, Figure S1: Molecular mass distributions of peptides.

Author Contributions: Conceptualization, C.L. and F.X.; investigation, J.P., S.Z., and Y.S.; writing-original draft preparation, C.L.; writing - review and editing, X.X.; project administration, X.X. All authors have read and agreed to the published version of the manuscript.

Funding: This research was funded by the Open Project of Chinese Materia Medica First-Class Discipline of Nanjing University of Chinese Medicine (No. 2020YLXK021).

Conflicts of Interest: The authors declare no conflict of interest.

\section{Abbreviations}

CSP films from chitosan and soy protein peptides

CCP films from chitosan and corn protein peptides

CCAP films from chitosan and casein peptides 


\section{References}

1. Hammam, A.R.A. Technological, applications, and characteristics of edible films and coatings: A review. $S N$ Appl. Sci. 2019, 1, 632. [CrossRef]

2. Mohamed, S.A.A.; El-Sakhawy, M.; El-Sakhawy, M.A.-M. Polysaccharides, protein and lipid-based natural edible films in food packaging: A review. Carbohydr. Polym. 2020, 238, 116178. [CrossRef] [PubMed]

3. Hassan, B.; Chatha, S.A.S.; Hussain, A.I.; Zia, K.M.; Akhtar, N. Recent advances on polysaccharides, lipids and protein based edible films and coatings: A review. Int. J. Biol. Macromol. 2018, 109, 1095-1107. [CrossRef] [PubMed]

4. Aguirre-Loredo, R.Y.; Rodríguez-Hernández, A.I.; Morales-Sánchez, E.; Gómez-Aldapa, C.A.; Velazquez, G. Effect of equilibrium moisture content on barrier, mechanical and thermal properties of chitosan films. Food Chem. 2016, 196, 560-566. [CrossRef] [PubMed]

5. Dutta, P.K.; Tripathi, S.; Mehrotra, G.; Dutta, J. Perspectives for chitosan based antimicrobial films in food applications. Food Chem. 2009, 114, 1173-1182. [CrossRef]

6. Liu, Y.; Yuan, Y.; Duan, S.; Li, C.; Hu, B.; Liu, A.; Wu, D.; Cui, H.; Lin, L.; He, J.; et al. Preparation and characterization of chitosan films with three kinds of molecular weight for food packaging. Int. J. Biol. Macromol. 2020, 155, 249-259. [CrossRef]

7. Mujtaba, M.; Morsi, R.E.; Kerch, G.; Elsabee, M.Z.; Kaya, M.; Labidi, J.; Khawar, K.M. Current advancements in chitosan-based film production for food technology: A review. Int. J. Biol. Macromol. 2019, 121, 889-904. [CrossRef]

8. Ahmed, M.K.; Moydeen, A.M.; Ismail, A.M.; El-Naggar, M.E.; Menazea, A.A.; El-Newehy, M.H. Wound dressing properties of functionalized environmentally biopolymer loaded with selenium nanoparticles. J. Mol. Struct. 2021, 1225, 129138. [CrossRef]

9. Elshaarawy, R.F.; Seif, G.A.; El-Naggar, M.E.; Mostafa, T.B.; El-Sawi, E.A. In-situ and ex-situ synthesis of poly-(imidazolium vanillyl)-grafted chitosan/silver nanobiocomposites for safe antibacterial finishing of cotton fabrics. Eur. Polym. J. 2019, 116, 210-221. [CrossRef]

10. Abdelgawad, A.M.; El-Naggar, M.E.; Hudson, S.M.; Rojas, O.J. Fabrication and characterization of bactericidal thiol-chitosan and chitosan iodoacetamide nanofibres. Int. J. Biol. Macromol. 2017, 94, 96-105. [CrossRef]

11. Rehan, M.; El-Naggar, M.E.; Mashaly, H.; Wilken, R. Nanocomposites based on chitosan/silver/clay for durable multi-functional properties of cotton fabrics. Carbohydr. Polym. 2018, 182, 29-41. [CrossRef] [PubMed]

12. Tan, W.; Dong, F.; Zhang, J.; Zhao, X.; Li, Q.; Guo, Z. Physical and antioxidant properties of edible chitosan ascorbate films. J. Agric. Food Chem. 2019, 67, 2530-2539. [CrossRef] [PubMed]

13. Zhang, L.; Zhang, Z.; Chen, Y.; Ma, X.; Xia, M. Chitosan and procyanidin composite films with high antioxidant activity and $\mathrm{pH}$ responsivity for cheese packaging. Food Chem. 2021, 338, 128013. [CrossRef] [PubMed]

14. López-Mata, M.A.; Ruiz-Cruz, S.; Ornelas-Paz, J.D.J.; del Toro-Sánchez, C.L.; Márquez-Ríos, E.; Silva-Beltrán, N.P.; Cira-Chávez, L.A.; Burruel-Ibarra, S.E. Mechanical, barrier and antioxidant properties of chitosan films incorporating cinnamaldehyde. J. Polym. Environ. 2018, 26, 452-461. [CrossRef]

15. Rambabu, K.; Bharath, G.; Banat, F.; Show, P.L.; Cocoletzi, H.H. Mango leaf extract incorporated chitosan antioxidant film for active food packaging. Int. J. Biol. Macromol. 2019, 126, 1234-1243.

16. Zhang, W.; Li, X.; Jiang, W. Development of antioxidant chitosan film with banana peels extract and its application as coating in maintaining the storage quality of apple. Int. J. Biol. Macromol. 2020, 154, 1205-1214. [CrossRef]

17. Lunkov, A.P.; Ilyina, A.V.; Varlamov, V.P. Antioxidant, antimicrobial, and fungicidal properties of chitosan based films (review). Appl. Biochem. Microbiol. 2018, 54, 449-458. [CrossRef]

18. Souza, V.G.; Fernando, A.L.; Pires, J.R.A.; Rodrigues, P.F.; Lopes, A.A.; Fernandes, F.M.B. Physical properties of chitosan films incorporated with natural antioxidants. Ind. Crops Prod. 2017, 107, 565-572. [CrossRef]

19. Lorenzo, J.; Munekata, P.E.; Gómez, B.; Barba, F.J.; Mora, L.; Pérez-Santaescolástica, C.; Toldrá, F. Bioactive peptides as natural antioxidants in food products-A review. Trends Food Sci. Technol. 2018, 79, $136-147$. [CrossRef] 
20. Giménez, B.; Estaca, J.G.; Alemán, A.; Guillén, M.C.G.; Montero, M. Improvement of the antioxidant properties of squid skin gelatin films by the addition of hydrolysates from squid gelatin. Food Hydrocoll. 2009, 23, 1322-1327. [CrossRef]

21. Zhang, C.; Wang, Z.; Li, Y.; Yang, Y.; Ju, X.; He, R. The preparation and physiochemical characterization of rapeseed protein hydrolysate-chitosan composite films. Food Chem. 2019, 272, 694-701. [CrossRef] [PubMed]

22. Hu, W.; Liu, M.; Yang, X.; Zhang, C.; Zhou, H.; Xie, W.; Fan, L.; Nie, M. Modification of chitosan grafted with collagen peptide by enzyme crosslinking. Carbohydr. Polym. 2019, 206, 468-475. [CrossRef]

23. Liu, M.; Min, L.; Zhu, C.; Rao, Z.; Liu, L.; Xu, W.; Luo, P.; Fan, L. Preparation, characterization and antioxidant activity of silk peptides grafted carboxymethyl chitosan. Int. J. Biol. Macromol. 2017, 104, 732-738. [CrossRef] [PubMed]

24. Rao, P.S.; Bajaj, R.; Mann, B. Impact of sequential enzymatic hydrolysis on antioxidant activity and peptide profile of casein hydrolysate. J. Food Sci. Technol. 2020, 57, 4562-4575. [CrossRef] [PubMed]

25. Wang, S.; Wang, J.; Xue, F.; Li, C. Effects of heating or ultrasound treatment on the enzymolysis and the structure characterization of hempseed protein isolates. J. Food Sci. Technol. 2019, 56, 3337-3346. [CrossRef]

26. Xue, F.; Gu, Y.; Wang, Y.; Li, C.; Adhikari, B. Encapsulation of essential oil in emulsion based edible films prepared by soy protein isolate-gum acacia conjugates. Food Hydrocoll. 2019, 96, 178-189. [CrossRef]

27. Rubilar, J.F.; Zúñiga, R.N.; Osorio, F.; Pedreschi, F. Physical properties of emulsion-based hydroxypropyl methylcellulose/whey protein isolate (HPMC/WPI) edible films. Carbohydr. Polym. 2015, 123, 27-38. [CrossRef]

28. Gheribi, R.; Puchot, L.; Verge, P.; Jaoued-Grayaa, N.; Mezni, M.; Habibi, Y.; Khwaldia, K. Development of plasticized edible films from Opuntia ficus-indica mucilage: A comparative study of various polyol plasticizers. Carbohydr. Polym. 2018, 190, 204-211. [CrossRef]

29. De Carvalho, R.; Grosso, C.R.F. Characterization of gelatin based films modified with transglutaminase, glyoxal and formaldehyde. Food Hydrocoll. 2004, 18, 717-726. [CrossRef]

30. Wang, K.; Wu, K.; Xiao, M.; Kuang, Y.; Corke, H.; Ni, X.; Jiang, F. Structural characterization and properties of konjac glucomannan and zein blend films. Int. J. Biol. Macromol. 2017, 105, 1096-1104. [CrossRef]

31. Li, C.; Wang, L.; Xue, F. Effects of conjugation between proteins and polysaccharides on the physical properties of emulsion-based edible films. J. Am. Oil Chem. Soc. 2019, 96, 1249-1263. [CrossRef]

32. Fakhouri, F.M.; Martelli, S.M.; Caon, T.; Velasco, J.I.; Buontempo, R.C.; Bilck, A.P.; Mei, L.H.I. The effect of fatty acids on the physicochemical properties of edible films composed of gelatin and gluten proteins. LWT 2018, 87, 293-300. [CrossRef]

33. Boributh, S.; Chanachai, A.; Jiraratananon, R. Modification of PVDF membrane by chitosan solution for reducing protein fouling. J. Membr. Sci. 2009, 342, 97-104. [CrossRef]

34. Lin, H.-C.; Wang, B.-J.; Weng, Y.-M. Development and characterization of sodium caseinate edible films cross-linked with genipin. LWT 2020, 118, 108813. [CrossRef]

35. Abugoch, L.E.; Tapia, C.; Villamán, M.C.; Yazdani-Pedram, M.; Díaz-Dosque, M. Characterization of quinoa protein-chitosan blend edible films. Food Hydrocoll. 2011, 25, 879-886. [CrossRef]

36. Ghanbarzadeh, B.; Mousavi, M.; Oromiehie, A.; Rezayi, K.; Rad, E.R.; Milani, J.M. Effect of plasticizing sugars on water vapor permeability, surface energy and microstructure properties of zein films. LWT Food Sci. Technol. 2007, 40, 1191-1197. [CrossRef]

37. Yin, Y.-C.; Yin, S.-W.; Yang, X.-Q.; Tang, C.-H.; Wen, S.-H.; Chen, Z.; Xiao, B.-J.; Wu, L.-Y. Surface modification of sodium caseinate films by zein coatings. Food Hydrocoll. 2014, 36, 1-8. [CrossRef]

38. Cao, L.; Liu, W.; Wang, L. Developing a green and edible film from Cassia gum: The effects of glycerol and sorbitol. J. Clean. Prod. 2018, 175, 276-282. [CrossRef]

39. Acevedo-Fani, A.; Salvia-Trujillo, L.; Rojas-Graü, M.A.; Martín-Belloso, O. Edible films from essential-oil-loaded nanoemulsions: Physicochemical characterization and antimicrobial properties. Food Hydrocoll. 2015, 47, 168-177. [CrossRef]

40. Kalaycıŏlu, Z.; Torlak, E.; Akın-Evingür, G.; Özen, I.; Erim, F.B. Antimicrobial and physical properties of chitosan films incorporated with turmeric extract. Int. J. Biol. Macromol. 2017, 101, 882-888. [CrossRef]

41. Liu, T.; Liu, L.; Gong, X.; Chi, F.; Ma, Z. Fabrication and comparison of active films from chitosan incorporating different spice extracts for shelf life extension of refrigerated pork. LWT 2021, 135, 110181. [CrossRef] 
42. Chu, Y.; Cheng, W.; Feng, X.; Gao, C.; Wu, D.; Meng, L.; Zhang, Y.; Tang, X. Fabrication, structure and properties of pullulan-based active films incorporated with ultrasound-assisted cinnamon essential oil nanoemulsions. Food Packag. Shelf Life 2020, 25, 100547. [CrossRef]

43. Zhang, X.; Liu, J.; Qian, C.; Kan, J.; Jin, C. Effect of grafting method on the physical property and antioxidant potential of chitosan film functionalized with gallic acid. Food Hydrocoll. 2019, 89, 1-10. [CrossRef]

44. Leceta, I.; Guerrero, P.; De La Caba, K. Functional properties of chitosan-based films. Carbohydr. Polym. 2013, 93, 339-346. [CrossRef] [PubMed]

45. Su, J.-F.; Huang, Z.; Yuan, X.-Y.; Wang, X.-Y.; Li, M. Structure and properties of carboxymethyl cellulose/soy protein isolate blend edible films crosslinked by maillard reactions. Carbohydr. Polym. 2010, 79, 145-153. [CrossRef]

46. Yang, G.; Xiong, X.; Zhang, L. Microporous formation of blend membranes from cellulose/konjac glucomannan in $\mathrm{NaOH} /$ thiourea aqueous solution. J. Membr. Sci. 2002, 201, 161-173. [CrossRef]

47. Affes, S.; Nasri, R.; Li, S.; Thami, T.; van der Lee, A.; Nasri, M.; Maalej, H. Effect of glucose-induced Maillard reaction on physical, structural and antioxidant properties of chitosan derivatives-based films. Carbohydr. Polym. 2020, 117341. [CrossRef]

48. Leceta, I.; Guerrero, P.; Ibarburu, I.; Dueñas, M.; de la Caba, K. Characterization and antimicrobial analysis of chitosan-based films. J. Food Eng. 2013, 116, 889-899. [CrossRef]

49. Martins, J.T.; Cerqueira, M.A.; Vicente, A.A. Influence of $\alpha$-tocopherol on physicochemical properties of chitosan-based films. Food Hydrocoll. 2012, 27, 220-227. [CrossRef]

50. Tripathi, S.; Mehrotra, G.; Dutta, P.K. Physicochemical and bioactivity of cross-linked chitosan-PVA film for food packaging applications. Int. J. Biol. Macromol. 2009, 45, 372-376. [CrossRef]

51. Pereda, M.; Amica, G.; Marcovich, N.E. Development and characterization of edible chitosan/olive oil emulsion films. Carbohydr. Polym. 2012, 87, 1318-1325. [CrossRef]

52. Sayari, N.; Sila, A.; Abdelmalek, B.E.; Abdallah, R.B.; Ellouz-Chaabouni, S.; Bougatef, A.; Balti, R. Chitin and chitosan from the Norway lobster by-products: Antimicrobial and anti-proliferative activities. Int. J. Biol. Macromol. 2016, 87, 163-171. [CrossRef] [PubMed]

53. Dehnad, D.; Mirzaei, H.; Emam-Djomeh, Z.; Jafari, S.M.; Dadashi, S. Thermal and antimicrobial properties of chitosan-nanocellulose films for extending shelf life of ground meat. Carbohydr. Polym. 2014, 109, 148-154. [CrossRef] [PubMed]

54. Akalın, A.S. Dairy-derived antimicrobial peptides: Action mechanisms, pharmaceutical uses and production proposals. Trends Food Sci. Technol. 2014, 36, 79-95. [CrossRef]

55. López-Expósito, I.; Gómez-Ruiz, J.Á.; Amigo, L.; Recio, I. Identification of antibacterial peptides from ovine as2-casein. Int. Dairy J. 2006, 16, 1072-1080. [CrossRef]

56. Hayes, M.; Ross, R.P.; Fitzgerald, G.F.; Hill, C.; Stanton, C. Casein-derived antimicrobial peptides generated by Lactobacillus acidophilus DPC6026. Appl. Environ. Microbiol. 2006, 72, 2260-2264. [CrossRef]

57. Norberg, S.; O'Connor, P.M.; Stanton, C.; Ross, R.P.; Hill, C.; Fitzgerald, G.F.; Cotter, P.D. Altering the composition of caseicins $\mathrm{A}$ and $\mathrm{B}$ as a means of determining the contribution of specific residues to antimicrobial activity. Appl. Environ. Microbiol. 2011, 77, 2496-2501. [CrossRef]

58. McCann, K.; Shiell, B.; Michalski, W.; Lee, A.; Wan, J.; Roginski, H.; Coventry, M. Isolation and characterisation of a novel antibacterial peptide from bovine $\alpha$ S1-casein. Int. Dairy J. 2006, 16, 316-323. [CrossRef]

59. Wen, C.; Zhang, J.; Zhang, H.; Duan, Y.; Ma, H. Plant protein-derived antioxidant peptides: Isolation, identification, mechanism of action and application in food systems: A review. Trends Food Sci. Technol. 2020, 105, 308-322. [CrossRef]

60. Beermann, C.; Euler, M.; Herzberg, J.; Stahl, B. Anti-oxidative capacity of enzymatically released peptides from soybean protein isolate. Eur. Food Res. Technol. 2009, 229, 637-644. [CrossRef]

61. Jiang, X.; Cui, Z.; Wang, L.; Xu, H.; Zhang, Y. Production of bioactive peptides from corn gluten meal by solid-state fermentation with Bacillus subtilis MTCC5480 and evaluation of its antioxidant capacity in vivo. LWT 2020, 131, 109767. [CrossRef] 
62. Shazly, A.B.; Chen, J.; El-Aziz, M.A.; Zeng, M.; Zhang, S.; Qin, F.; Chen, J. Fractionation and identification of novel antioxidant peptides from buffalo and bovine casein hydrolysates. Food Chem. 2017, 232, 753-762. [CrossRef] [PubMed]

Publisher's Note: MDPI stays neutral with regard to jurisdictional claims in published maps and institutional affiliations.

(C) 2020 by the authors. Licensee MDPI, Basel, Switzerland. This article is an open access article distributed under the terms and conditions of the Creative Commons Attribution (CC BY) license (http://creativecommons.org/licenses/by/4.0/). 